\title{
Analyzing the Effectiveness of Policy Implementation at the Local Level: A Case Study of Management of the 2009-2010 Drought in Yunnan Province, China
}

\author{
Neera Shrestha Pradhan ${ }^{1,2,3} \cdot$ Yufang $\mathrm{Su}^{4,5} \cdot$ Yao Fu ${ }^{3} \cdot$ Liyun Zhang ${ }^{6}$. \\ Yongping Yang ${ }^{3}$
}

Published online: 28 March 2017

(C) The Author(s) 2017. This article is an open access publication

\begin{abstract}
Several research efforts have focused primarily on policy implementation and improving innovative actions to address disaster risks. Discussions are ongoing on how to measure the effectiveness of policy implementation at the local level. But there is no definitive theory of effective policy implementation, and very few frameworks have been found acceptable as the basis of an analysis of the effectiveness of policy implementation, especially on droughts. Based on the 2009-2010 extreme drought in Yunnan, China, this article presents a modified framework to assess the effectiveness of policy implementation by defining policy, practice, and performance, as well as a feedback loop by which to share the lessons learned. Water conservancy projects in Luliang County and the agricultural diversity program in Longyang County in Yunnan Province were analyzed from a farmers' perspective. It was found that farmers are highly dependent on government policies and projects, and the effectiveness of policies is measured by short-term, immediate, and tangible benefits
\end{abstract}

Yongping Yang

yangyp@mail.kib.ac.cn

1 University of Chinese Academy of Sciences, Beijing 100049, China

2 International Centre for Integrated Mountain Development (ICIMOD), Kathmandu, Nepal

3 Kunming Institute of Botany (KIB), Chinese Academy of Sciences, Kunming 650201, Yunnan, China

4 Centre for Mountain Ecosystem Studies, Kunming Institute of Botany, Kunming 650201, Yunnan, China

5 Yunnan Academy of Social Science, Kunming 650034, Yunnan, China

6 Institute of International Rivers and Eco-Security, Yunnan University, Kunming 650091, Yunnan, China rather than long-term adaptation strategies. The results highlight the urgent need to reduce risks by developing better awareness about climate change and drought and its impacts, increased understanding of drought hazards, and implementation of appropriate measures for long-term adaptation.

Keywords China $\cdot$ Community perception - Drought impact - Local adaptation strategies · Policy implementation and effectiveness - Yunnan Province

\section{Introduction}

Extreme events, such as floods and droughts, are receiving significant attention due to their serious impact on economy, society, and the environment, which leads to impacts on natural, physical, financial, human, and social, and cultural assets (Mimura et al. 2014). The 2001-2010 decade saw extreme droughts in most parts of the world-the highest impact and long-term droughts in Australia (2002 and other years), East Africa (2004 and 2005, resulting in widespread loss of life), and the Amazon Basin (2010) with negative impacts on the environment (Sivakumar 2013). Since the founding of the People's Republic of China, a 3-year-long drought during 1999-2001 ranked the most sever with an area of impact, duration, and induced losses rarely seen in the country's history. Another large-scale drought disaster occurred in five provinces of China in 2009-2010 and threatened more than 70 million people with drinking water shortages and barren farmlands. During its peak period, over 20 million people and 30 million livestock suffered from temporary water shortages (Zou and Yuan 2010). 
In order to address drought impact, China has formulated a number of policies for drought relief, mitigation and adaption, and enhanced adaptive capacity (Li et al. 2012, 2013). Some policies are adopted at multiple levels of government in China (Teng and Gu 2007; Li et al. 2012, 2013). China's centralized policies on climate change either operate directly at appropriate levels or give space to subnational authorities to choose the elements of central government policy that they wish to promote and provide subsidies accordingly. Our literature review showed that policies are implemented through the government's five-tier hierarchical structure (Teng and $\mathrm{Gu}$ 2007). The central government in Beijing is responsible for making policies and programs. The four tiers of local government-provincial, city, county, and township-implement the programs and have the power to hire and fire departmental employees. The evaluation and promotion of government employees provide strong incentives based on economic growth and local development, disregarding environmental sustainability.

Teng and Gu's (2007) study argued that successful policy implementation was dependent on good linkages between different levels of government and organizations at the local level and that any missing linkage results in an "implementation gap." Researchers also debated about policy implementation and presented two major schools of thought: the top-down approach and the bottom-up approach (Matland 1995; O'Toole 2000). The top-down approach emphasizes central actors like the national government and bureaucrats as policymakers who focus on a central implementation strategy. The bottom-up approach stresses the target groups and the service deliverers as important actors who need to be involved in the policymaking process.

Some research effort and discussion have focused on improving policies and implementing innovative actions to address disaster risks, as well as measuring the effectiveness of policy implementation at the local level. New knowledge about best practices is necessary but there is no definitive framework as a baseline to analyze the effectiveness of policy implementation. Our literature review shows that some policy effectiveness studies have been conducted in the environmental sector like diverting waste from landfill (European Environment Agency n.d., 2009); British Colombia's mining development (Baker and McLelland 2003); the health sector policy reform (Potter and Harries 2006); and organic farming policy in Thailand (Mingchai and Yossuck 2008).

The effectiveness of policy implementation documented for environmental assessments, explains the concept of an "effectiveness triangle" (Sadler 1996). The term "effectiveness" is explained by Sadler as whether something works as intended and meets the purpose for which it is designed. Environmental assessments aim to facilitate sound, integrated decision making by providing clear, wellorganized information on the environmental effects, risks, and consequences that must be considered to achieve the ultimate goals of environmental protection and sustainable development. Effectiveness is evaluated by Sadler using three generic criteria: procedural (to meet accepted principles and provisions), substantive (to achieve established purposes and objectives), and transactive (to determine the extent to which the procedural principles deliver the substantive objectives at the least cost and in the minimum time possible). Ultimately, overall effectiveness is achieved if it supports policy and institutional reforms to the decision-making process of environmental protection and sustainable development.

Based on Sadler's theory of "effectiveness triangle," Baker and McLelland (2003) proposed an expanded framework that focuses on policy as a function of the different aspects of efficacy that surround the policy (Baker and McLelland 2003). Procedural (practice), substantive (performance), and transactive (proficiency) aspects were defined and a normative (purpose) aspect was added by Baker and McLelland (2003). The expanded framework represented "circular effectiveness cycle" linking all four aspects to analyze policy effectiveness. The framework was used to trace the practice of a given policy by understanding how the policy was applied and what procedures were followed. Examination of the performance and proficiency involved in the implementation process allows a clear understanding of how the policy objectives were met, and how resources were used to achieve the objectives. Examination of the normative aspect included an analysis to find out whether purposed goals were realized by the policy. Overall policy effectiveness was reflected through this by the extent to which a policy works from all four aspects of the circular effectiveness cycle. This framework was tested in Mount Milligan, Kemess, and Huckleburry cases of mine development in British Columbia and analyzed to determine the effectiveness of First Nations' participation in the environmental assessment process (Baker and McLelland 2003).

Examination of the effectiveness of policy implementation regarding natural hazards and climate-induced disasters such as floods, flash floods, and droughts remains a major gap and an important research area (Chen et al. 2014). Discussions are ongoing on how empirical research that focuses on governance and policy making can inform the adaptation literature, and what happens when the best laid plans meet the real world, which can crucially affect policy outcomes (Eakin and Lemos 2006). Although state policies will continue to play a key role in shaping adaptation options, it is equally important to enhance the adaptive capacity of people. Since most local-level policies 
are responsive to directives from higher levels of government, there is an opportunity to integrate national goals into sectoral policies and action plans at the local level ( $\mathrm{Su}$ et al. 2012). Yet questions remain unanswered on how to increase adaptive capacity of local communities to ongoing changes and extreme events (Chen et al. 2014).

This article addresses two key questions: (1) What are the local coping/adaptation practices employed to deal with drought? and (2) How do farmers perceive the effectiveness of policy implementation at the local level? These questions will help policymakers not only to better understand farmers' responses to drought, but also provide an insight on policy effectiveness, and support the formulation and implementation of plans and policies by considering their effectiveness at the local level.

\section{Research Methodology}

A qualitative method was adopted for the study to address the exploratory nature of the research and perception study (Gillham 2005; Castellan 2010). This study conceptualized a framework to analyze the effectiveness of policy implementation, with a specific focus on drought management in Yunnan Province, China. The framework defines the policy (what were the measures taken), practice (what happened), and performance (what were the results) to assess the effectiveness of policy implementation. The feedback loops between policy, practice, and performance provide inputs to decision makers for planning and implementing policies on the ground. To analyze the effectiveness of policy implementation, two case studies in Yunnan-water conservancy projects in Luliang County and agricultural diversity program in Longyang County-were considered.

\subsection{Study Area}

Yunnan Province, the eighth largest province in China, is situated on the country's southwest frontier and covers nearly $4.1 \%$ of the total area of China. Over $70 \%$ of the province's water resources are located in remote mountainous areas. A karst landscape dominates much of Yunnan. Soft rocks in these areas result in sinkholes and extensive underground, rather than surface, drainage, which makes access to water resources difficult and largely local. This creates a big gap between supply and demand, and results in water shortage in cities and the frequent occurrence of drought disasters. Drought is one of the most severe disasters that affects agricultural production in Yunnan. Based on the severe impact of droughts experienced during 2009-2010, Qujing and Baoshan Cities in Yunnan Province were selected for this research (Fig. 1).
Situated in northeastern Yunnan, Qujing is the second largest city by population and was one of the most droughtimpacted areas in 2009-2010 (Wang and Meng 2013). Qujing has a subtropical highland climate, with short, mild, dry winters, and warm, rainy summers. Luliang Countyone of Qujing's nine counties/districts-was purposively selected for this research because of the region's historical background. In the 1960s Luliang was impacted by a great famine and a series of other extreme events, for example the 2009-2010 drought when the then Premier Wen Jiabao visited to appeal to the local government to take necessary relief measures immediately (Xinhua 2010). Two administrative village groups, Fa-e-sha and Ayoupu, were selected based on drought severity, economic status, geological conditions, and the number of projects implemented by the government after the 2009-2010 drought.

Baoshan, located in western Yunnan, is the third biggest city in the province. It is one of the foremost agricultural production areas in a region where more than $88.5 \%$ of the population depend on agriculture, and the area has a long tradition of tree crop cultivation. The 2009-2010 drought in Baoshan was the worst reported in 100 years. While all counties in Baoshan experienced a reduction in rainfall during that time, the study areas (Haitang, Shuiyan, and Xinzhai villages located in Longyang County) experienced the highest reductions in rainfall rates. These villages represent different levels of engagement in tree planting on farms at elevations ranging from 950 to $2473 \mathrm{~m}$ (Table 1).

\subsection{Research Design}

The field survey was conducted in two phases, Luliang in 2013-2015 and Longyang in 2010-2012 (as a part of a larger research project). The sample was selected using a purposive sampling method ensuring the reliability and quality of data collection. In Luliang, four levels of key informant interviews provided an understanding of the policy implementation process in the villager groups (lowest administrative level) and the involvement of communities in the decision making for project implementation. The key informants were 1 former county governor, 2 township water managers, 2 village leaders, and 12 villager group leaders. Focus group discussions (with a mix of ethnicity, age, and household responsibilities) were conducted with 11 women's groups (total 91 participants) and 11 men's groups (total 95 participants) separately. In order to get the holistic picture of the communities' perception and to ensure that women's responses are not influenced by men's opinion and vice versa, it was important to separate the two groups while conducting the research. The key informants were not included in the focus group discussions to avoid duplication. In Longyang, 


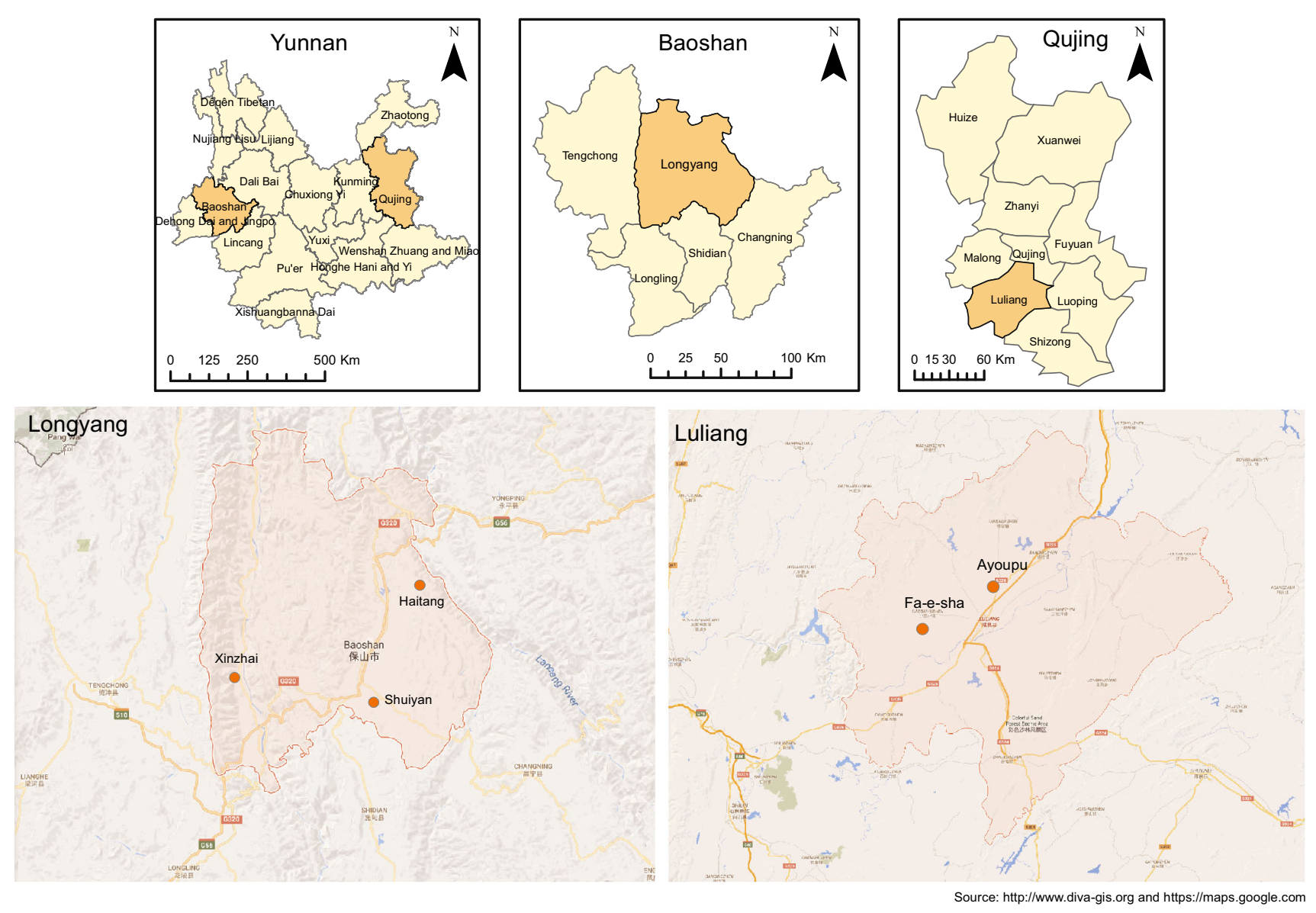

Fig. 1 Study areas in Yunnan Province, China. Source http://www.diva-gis.org and https://maps.google.com

key informant interviews were conducted with 6 village heads, 2 agriculture extension technicians, 3 township level government officials; a further 3 semistructured focus group discussions were held. In addition, 40 households in Haitang, 42 households in Shuiyan, and 41 households in Xinzhai were interviewed using a structured questionnaire to gather information regarding the resilience of different crops under drought and the implications for household adaptive capacity.

A detailed checklist including general information, village information, drought management, policy process, and policy instrument and implementation at the local level was prepared for the questionnaire survey with key informants and the household survey. The data were collected with the help of trained research assistants to facilitate the household survey and focus group discussions in local dialect. Resource maps drawn by the key informants during the interviews were used to understand the social structure and resources. In addition to the socioeconomic and policy information gathered from the field survey, hydrological and meteorological data in Luliang and Longyang stations were collected for the period of 1980-2014 and analyzed to understand trends in temperature and rainfall. The research used a case study approach to analyze the effectiveness of policy implementation in Yunnan Province that was intended to address drought.

A qualitative analysis was conducted to understand participants' perception of drought. Transcripts of the key informant interviews and focus group discussions, notes from field observations, and social maps were used for data analysis (Schutt 1996). Because the study uses a case study approach and the purpose is to understand, contextualize, and interpret the situation by interacting with the communities to get to the core of the issue, qualitative methods of data collection and analysis were selected (Castellan 2010). Data triangulation was conducted using focus group discussions, key informant interviews, literature/policy study, and results are presented in narrative form to describe themes.

\section{Framework for Measuring Effectiveness of Policy Implementation}

This article conceptualizes a modified framework for measuring the effectiveness of policy implementation in the case of an extreme event like drought (Fig. 2). The 
Table 1 Characteristics of the study sites in Yunnan Province, China. Source http://www.luliang.gov.cn/ (unofficial translation); Xinzhai: http:// www.ynszxc.gov.cn/S1/S1364/S1365/S1778/S12707/; Haitang: http://www.ynszxc.gov.cn/S1/S1364/S1365/S1382/S112367/; Shuiyan: http:// www.ynszxc.gov.cn/S1/S1364/S1365/S1371/S170122/; Field survey 2013-2015 (Luliang) and 2010-2012 (Longyang)

\begin{tabular}{|c|c|c|c|c|c|}
\hline & Luliang & & Longyang & & \\
\hline $\begin{array}{l}\text { Administrative } \\
\text { villages }\end{array}$ & Ayoupu & Fa-e-sha & Xinzhai & Shuiyan & Haitang \\
\hline Elevation (m) & 1907 & 1876 & 950 & 1720 & 2473 \\
\hline No. of households & $1906(2011)$ & 958 (2011) & 696 (2015) & 570 (2010) & 365 (2014) \\
\hline $\begin{array}{l}\text { No. of villager } \\
\text { groups }\end{array}$ & 4 & 8 & 9 & 10 & 6 \\
\hline Population & $\begin{array}{l}6450 \text { (3266 male, } \\
3184 \text { female) }\end{array}$ & $\begin{array}{c}3560 \text { (1827 male, } \\
1733 \text { female) }\end{array}$ & $\begin{array}{l}2112(1054 \\
\quad \text { male, } 1058 \\
\text { female })\end{array}$ & $\begin{array}{l}2412 \text { (1221 male, } \\
1191 \text { female) }\end{array}$ & $\begin{array}{l}1581 \text { (808 male, } \\
773 \text { female) }\end{array}$ \\
\hline Land area $\left(\mathrm{km}^{2}\right)$ & 24.47 & 30.78 & 16.59 & 12.68 & 14 \\
\hline $\begin{array}{l}\text { Average } \\
\text { temperature }{ }^{\circ} \mathrm{C}\end{array}$ & 14.7 & 14.7 & 21 & 16 & 12.2 \\
\hline $\begin{array}{l}\text { Average annual } \\
\text { rainfall }(\mathrm{mm})\end{array}$ & 675 & 580 & 700 & 1200 & 1200 \\
\hline $\begin{array}{l}\text { Temperature } \\
\text { trend based on } \\
\text { field survey }\end{array}$ & Increasing & Increasing & Increasing & Increasing & Increasing \\
\hline $\begin{array}{l}\text { Major stress as } \\
\text { perceived by } \\
\text { the community }\end{array}$ & $\begin{array}{l}\text { Water shortage due } \\
\text { to less rainfall }\end{array}$ & $\begin{array}{l}\text { Water shortage due } \\
\text { to drying of } \\
\text { ponds }\end{array}$ & $\begin{array}{l}\text { Water shortage } \\
\text { in the spring } \\
\text { and droughts }\end{array}$ & $\begin{array}{l}\text { Water shortage } \\
\text { in the spring } \\
\text { and hail in the } \\
\text { summer/ } \\
\text { autumn, and } \\
\text { droughts }\end{array}$ & $\begin{array}{l}\text { Water shortage in } \\
\text { the spring }\end{array}$ \\
\hline Agriculture base & $\begin{array}{l}\text { Corn, tobacco, rice, } \\
\text { and other crops }\end{array}$ & $\begin{array}{l}\text { Corn, rice, tobacco, } \\
\text { and other crops }\end{array}$ & Coffee & $\begin{array}{l}\text { Tobacco, walnuts, } \\
\text { pears, plums }\end{array}$ & $\begin{array}{l}\text { Mushrooms, pine } \\
\text { nuts and walnuts, } \\
\text { Sichuan peppers, } \\
\text { timber, grain, } \\
\text { tobacco }\end{array}$ \\
\hline $\begin{array}{l}\text { Physical } \\
\text { infrastructure } \\
\text { and facilities }\end{array}$ & $\begin{array}{l}\text { Road to reach township } \\
0.5 \mathrm{~km} \text {, nearest bazaar } \\
2 \mathrm{~km} \text {; asphalt road with } \\
\text { concrete pavement }\end{array}$ & $\begin{array}{l}\text { Road to reach } \\
\text { township } 7 \mathrm{~km}, 7 \mathrm{~km} \\
\text { from the nearest } \\
\text { bazaars; gravel road }\end{array}$ & $\begin{array}{l}\text { Paved road to } \\
\text { reach } \\
\text { township } \\
\text { about } 10 \mathrm{~km}\end{array}$ & $\begin{array}{l}\text { Paved road to } \\
\text { reach township } \\
\text { about } 8 \mathrm{~km}\end{array}$ & $\begin{array}{l}\text { Paved road to reach } \\
\text { township about } \\
11 \mathrm{~km}\end{array}$ \\
\hline
\end{tabular}

modified framework is based on Sadler's (1996) and Baker and McLelland's (2003) framework to measure the effectiveness. It relates policy to practice to performance, as well as the implications of performance to policy adjustments and process development. In addition to the Sadler's and Baker and McLelland's framework, and as explained by Matland (1995), the modified framework incorporates a bottom-up approach to consider policy implementation and contextualizes it to analyze the impact of drought on the ground (Matland 1995). Although the major focus is on relating policy to practice and practice to performance, this modified framework emphasizes an additional step, which is the feedback loop to link performance to policy adjustments and process development. The feedback loop is important to improvise and implement policy effectively at the local level.
The framework, developed to measure the effectiveness of policy implementation for extreme events, is implemented by conducting three major steps. After the identification of the issues that are pertinent to a defined geographical area, the first step is to describe the purpose for which those issues were prioritized and the relevant policy measures taken to address them. The second step looks into the planning approach and examines the policymaking process leading to the selection of appropriate practices on the ground. The third step analyzes the implementation of the policy in order to measure its effectiveness. The indicators of effective policy implementation may vary for the same issue (drought in this case) depending on the perceptions of the communities (Yang and Holzer 2006), and their geophysical location (Scheumann and Kraume 2009; Vaidya 2009). A feedback 


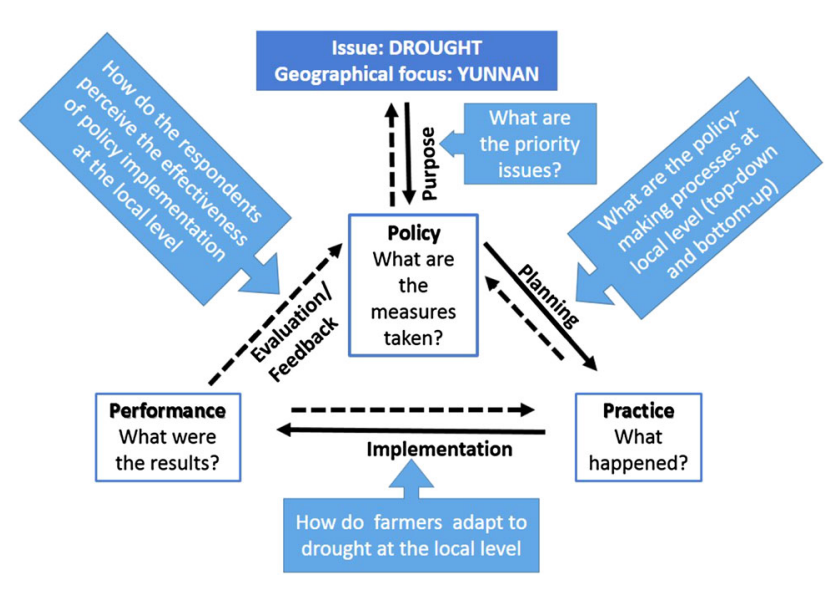

Fig. 2 Modified framework to analyze the effectiveness of policy implementation. Source Modified framework based on the concept presented by Sadler's "effectiveness triangle" and Baker and McLelland's "circular effectiveness cycle"; literature review and field research, 2013-2016

loop exists in every step to provide inputs to policy and decision makers. This framework is considered to be evolving and, with experience and inputs, can be modified as further research takes place. Each of the components is described below.

\subsection{Policy}

In this framework, policy is defined as the laws, ordinances, and rules, as well as the government (or other) support to implement projects on the ground (Chen et al. 2014). The definition of policy can be described as the ability to apply control over the issue being addressed in a defined geographic area (villager group, administrative village, township) in relation to specific social groups (domestic water users, agriculture water users, villager groups), instruments (government funds, private sector support), actors (villager group leaders, village leaders, township water managers), and mechanisms (projects, infrastructure, and technologies) for successful operation.

\subsection{Practice}

Examination of the practices that communities are adopting involves understanding of the local policy planning process (Baker and McLelland 2003). The planning process could be top-down or bottom-up, but adaptation planning should take place in an interface of top-down and bottom-up approaches (Pradhan et al. 2014). In most cases, communities in the region are already adapting to changes, including climate change. These autonomous adaptations require an enabling policy environment for their effective implementation. Yet the major challenge to the implementation of planned adaptation is that it is likely to require a long period of trial and error, whereas autonomous adaptation strategies are an immediate option for many vulnerable people (Pradhan et al. 2012).

\subsection{Performance}

The performance indicators examine whether the objectives were met as a result of the application of plans/ practices (Baker and McLelland 2003). The assessment addresses how communities adapt at the local level and analyzes communities' perception of policy effectiveness (Chen et al. 2014), which provides feedback for policy improvement. A feedback loop also exists between performance and practice, and practice and policy. Performance depends on the vulnerability and the adaptive capacity of the communities to deal with the effects or risks associated with the exposures. It is also important to understand that the adaptive capacity of a community is dynamic and varies in different communities, geographical context, social and political conditions, and various drivers of change (Adger et al. 2005; Smit and Wandel 2006). The feedback from performance leads to adjustments to improve the meeting of objectives by future policy applications (Baker and McLelland 2003).

\subsection{Overall Effectiveness}

The overall effectiveness of policy implementation is determined by understanding the purpose for which policy implementation takes place. Proper planning leads to good practices, and their implementation results in better performance that provides feedback for policy and decision makers. The success of policy implementation depends on the choice of appropriate incentives based on the local biophysical and social conditions (Li et al. 2013). Evaluating the effectiveness of policy implementation helps raise important questions like "Are the policies working? What needs to be improved? What could be the feedback mechanism in the policy cycle?"

\section{Findings}

Due to the limited literature available that presents frameworks by which to analyze the effectiveness of policy implementation, especially in the field of disaster management, this article develops a modified framework. This framework is used to analyze the effectiveness of policy implementation for drought, but could also be applied to the disaster risks of floods, flash floods, landslides, and other disasters, as well as in different geographical areas.

Though different policies are implemented in the research sites, water conservancy projects in Luliang and 
agricultural diversity programs in Longyang were prioritized based on the intense discussion with the experts and key informants. The findings of the two case studies are summarized and presented in Table 2 using the modified framework.

\subsection{Case Study 1: Water Conservancy Project in Luliang County}

Water shortage due to lower rainfall and drying ponds and other water sources were the major issues in the two selected villages, Ayoupu and Fa-e-sha, in Luliang County. According to the key informant interviews, the most important impact perceived by $50 \%(n=16)$ of the local leaders was the scarcity of water for drinking and agriculture. The farmers perceived the cause for drought differently-difficult geological condition (karst landscape), land use change (construction of roads, plantations of eucalyptus trees), no technology available for wise use of water (water harvesting and sprinkler), and high dependency on government funds. Almost $100 \%$ of the key informants $(n=16)$ and the participants in the focus group discussions $(n=22)$ perceived that the temperature is increasing but the rainfall is decreasing compared to past 10 years. This experimental perspective was also validated by the research team's temperature and rainfall trend analysis that used data from the Meteorological Bureau.

The average annual temperature in Luliang has been increasing since the 1990s, after a long lower temperature period (Fig. 3). Linear trend analyses show that, during the period 1980-2014, the average annual temperature in Luliang increased at a rate of $0.3{ }^{\circ} \mathrm{C} /$ decade $\left(R^{2}=0.3814\right)$, and a warming trend of $0.18^{\circ} \mathrm{C} /$ decade $\left(R^{2}=0.2477\right)$ and $0.41{ }^{\circ} \mathrm{C} /$ decade $\left(R^{2}=0.2202\right)$ was observed for the summer and winter temperatures, respectively. This shows that the temperature in winter was warming at a higher rate than that in summer. The annual temperature change trend in Luliang is consistent with that of Yunnan Province. Summer temperatures in Luliang follows the same trend as Yunnan, but winter temperatures show a slightly higher warming trend than the provincial average, indicating that Luliang is slightly more vulnerable to drought. The annual precipitation pattern during the period 1980-2014 in Luliang shows a decreasing trend, which follows the decreasing trend of the provincial annual precipitation.

In order to address drought, the Yunnan Provincial Government promulgated guidelines in 2011 to steer water conservancy development in the province. These directives encompassed large-scale water conservancy projects and

Table 2 The effectiveness of policy implementation analyzed using the modified framework

\begin{tabular}{|c|c|c|c|}
\hline \multicolumn{2}{|l|}{ Issue: drought } & \multicolumn{2}{|l|}{ Geographical focus } \\
\hline $\begin{array}{l}\text { Framework } \\
\text { elements }\end{array}$ & Key questions & Ayoupu and Fa-e-sha villages in Luliang & $\begin{array}{l}\text { Xinzhai, Shuiyan, and Haitang villages in } \\
\text { Longyang }\end{array}$ \\
\hline Purpose & $\begin{array}{l}\text { What are the priority } \\
\text { issues? }\end{array}$ & $\begin{array}{l}\text { To minimize domestic and agricultural water } \\
\text { stress at the local level }\end{array}$ & $\begin{array}{l}\text { To minimize domestic and agricultural water } \\
\text { stress at the local level }\end{array}$ \\
\hline Policy & $\begin{array}{l}\text { What are the } \\
\text { measures taken? }\end{array}$ & $\begin{array}{l}\text { Water conservancy projects (e.g., five small water } \\
\text { project, agricultural road project, etc.) }\end{array}$ & Agricultural diversity (tree crops) \\
\hline Planning & $\begin{array}{l}\text { What is the policy- } \\
\text { making process at } \\
\text { the local level? }\end{array}$ & $\begin{array}{l}\text { The funding for projects are channeled top-down, } \\
\text { whereas, the planning and prioritization process } \\
\text { is bottom-up }\end{array}$ & $\begin{array}{l}\text { Government announces specific lines of funding } \\
\text { available and village leaders make contacts } \\
\text { with respective government departments to } \\
\text { have their project/proposal selected }\end{array}$ \\
\hline Practice & What happened? & $\begin{array}{l}\text { Government and tobacco companies provided } \\
\text { support to address the issues }\end{array}$ & $\begin{array}{l}\text { Government provided support to address the } \\
\text { issues }\end{array}$ \\
\hline Implementation & $\begin{array}{l}\text { How do farmers } \\
\text { adapt to drought at } \\
\text { the local level? }\end{array}$ & $\begin{array}{l}\text { Infrastructure development, human mobility for } \\
\text { employment opportunities }\end{array}$ & $\begin{array}{l}\text { Expansion of perennial cash crops, sale of assets } \\
\text { such as livestock, engagement in off-farm work }\end{array}$ \\
\hline Performance & $\begin{array}{l}\text { What were the } \\
\text { results }\end{array}$ & $\begin{array}{l}\text { Support from government and company helped } \\
\text { the communities with short-term coping to } \\
\text { drought, however, long-term adaptation was } \\
\text { not their priority }\end{array}$ & $\begin{array}{l}\text { Trees played a variety of roles in enhancing the } \\
\text { adaptive capacity of households, however, } \\
\text { monoculture production made the communities } \\
\text { more vulnerable to climate stress }\end{array}$ \\
\hline $\begin{array}{r}\text { Evaluation/ } \\
\text { feedback }\end{array}$ & $\begin{array}{l}\text { What are the } \\
\text { recommendations? }\end{array}$ & $\begin{array}{l}\text { Long-term adaptation planning like water } \\
\text { harvesting, water-efficient technology, } \\
\text { watershed management, and resource } \\
\text { conservation to build the resilience of the } \\
\text { communities to deal with drought }\end{array}$ & $\begin{array}{l}\text { Diversification of income and agricultural crops, } \\
\text { including tree crops, are important to improve } \\
\text { the resilience of the communities to deal with } \\
\text { drought }\end{array}$ \\
\hline
\end{tabular}




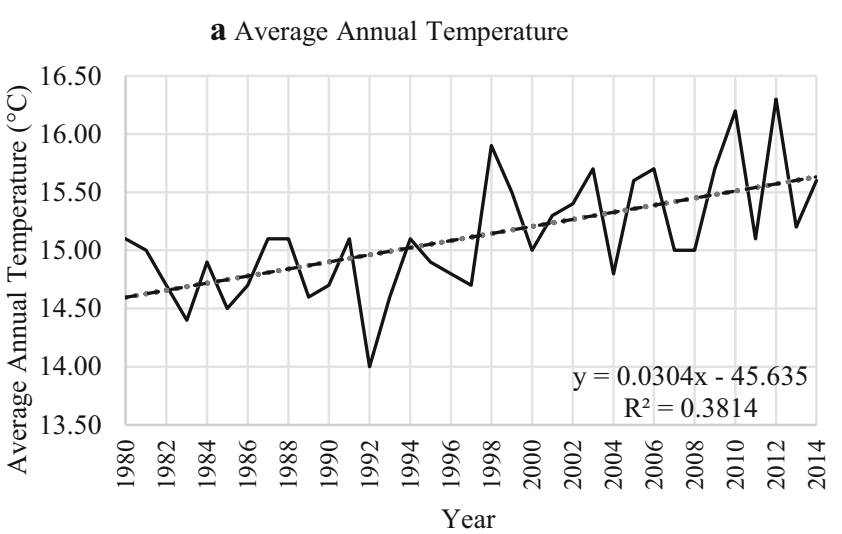

b Average Summer Temperature

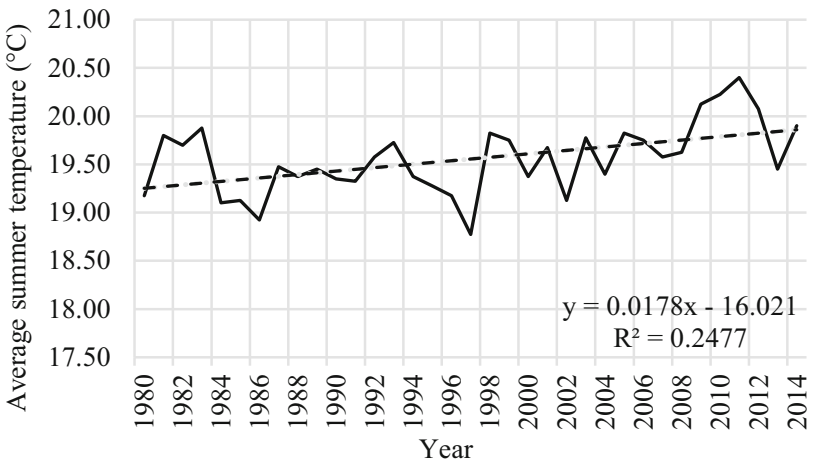

c Average Winter Temperature

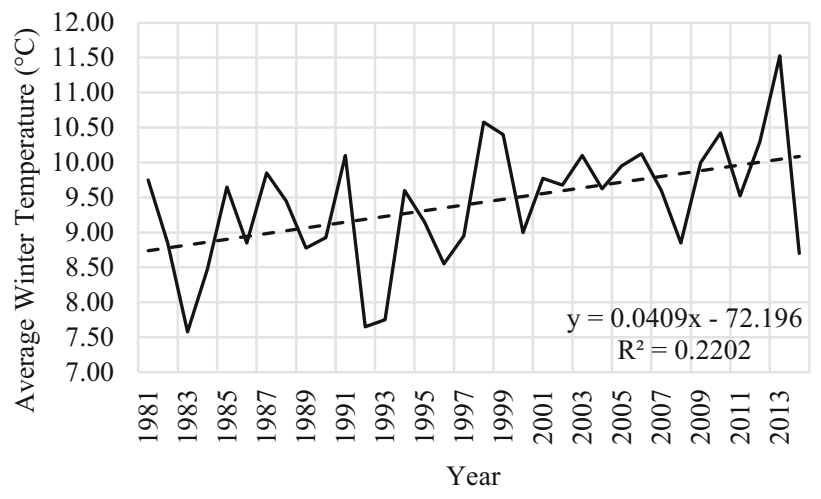

d Annual Precipitation

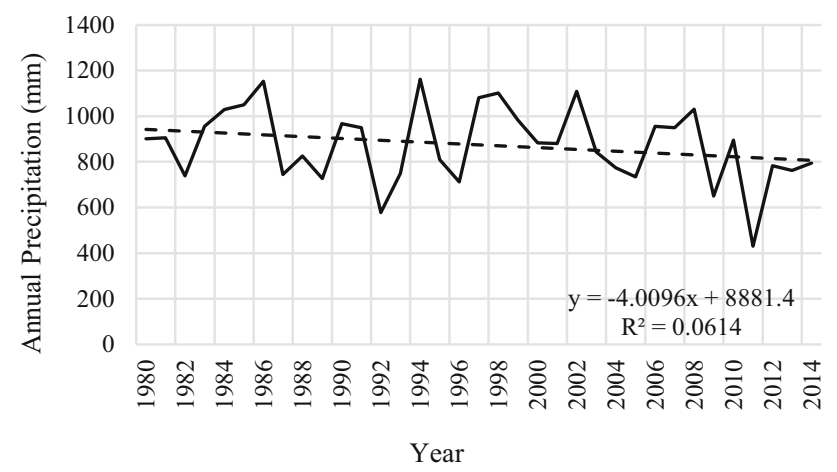

Fig. 3 Average a annual, b summer, and c winter temperatures, and d annual precipitation, for the period 1980-2014 for Luliang County, Yunnan Province, China. Data source Qujing Meteorological Bureau, Yunnan Province

micro-scale water conservancy projects that facilitate development on farmland, encourage private sector investment, and establish market-based water price systems. ${ }^{1}$ Since tobacco production is one of Yunnan's pillar industries, the government cooperated with tobacco companies for policy support on irrigation development, farmland improvement, and water-saving technologies.

The People's Congress of Yunnan Province published the Ordinance of Water-Saving in Yunnan ${ }^{2}$ in 2012 in response to the 2009-2010 drought in order to promote water saving and increase water-use efficiency. It became a legally binding obligation at all levels of government in Yunnan to incorporate water saving into their socioeconomic development plans; professional technology standards were identified in industry to save water; individuals and organizations that make great contributions in watersaving technology research and extension or develop an innovation in saving water were rewarded; and subsidies and loans were provided for farmers to construct water conservancy projects and use water-saving technology.

\footnotetext{
${ }^{1}$ http://yn.yunnan.cn/html/2011-05/09/content_1601380_2.htm.

${ }^{2}$ http://jsb.km.gov.cn/c/2015-06-10/707501.shtml.
}

According to the township water managers and focus group discussions, the agriculture department built an access road, and the county government invested in a drinking-water project and "five small water" (small water vault, tank, pumping station, pond, and channel $)^{3}$ projects in Ayoupu. Since the road network and its condition is poor in Fa-e-sha, the farmers lack access to the market and are left with no option but to sell their goods in Damogu Township. Government policies such as water-saving technologies, skill training, and floating nurseries were introduced by tobacco companies in some villager groups, which helped farmers to deal with immediate drought problems. These changes in water management practices were highly influenced by government policies. In earlier times, the natural lakes and ponds were sufficient. Now, farmers pump water and depend on government infrastructure such as pipes, water tanks, and wells for drinking water. For agricultural production, the government and tobacco companies have introduced new technology that use plastic covers, drip irrigation, and sprinklers, and

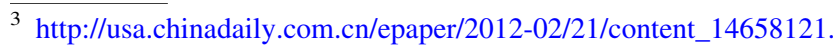
htm.
} 
introduced crop varieties that consume less water like maize/corns to make wise use of scarce water resources.

According to the key informant interview and focus group discussion, a feedback loop existed at the local level, where farmers prioritize their needs and submit project proposals to the administrative village leaders. The administrative village leaders collect the information and pass it on to the relevant township officials (for example, the township water manager in the case of water-related issues) for funding decisions. This system follows a bottom-up approach for project planning. In some cases, the farmers were also consulted before starting projects (Table 3). One of the villager group leaders said, "For every project, the government will send someone to this village to talk with me. I gather the villagers to talk about the project and ask whether they agree or disagree." If the township office has already received funds from the county, it will provide the funds to the administrative villages on a priority basis. If not, then the township office will ask the county government and the city government for the required funding. Not all the projects secure funding, but, if approved, project funds are handed over to the concerned authorities for implementation following the same hierarchical pathway downwards.

Farmers' perception about effectiveness of policy implementation differs as is presented in Fig. 4. The farmers in Ayoupu perceived water-use efficiency projects, drought knowledge and technology, income diversification, and access to resources as more effective, whereas farmers in Fa-e-sha perceived government funds as more important for effective policy implementation. They perceived that drought knowledge, awareness, and governance structures, such as water-user groups at the local level, are less effective for policy implementation, especially if they do not have enough funds to implement the project. Because Ayoupu has influential leaders and more projects implemented by the government, the farmers in Fa-e-sha perceived that the role of leaders is important to influence the local government to provide funding support. But governance structure and community participation were considered less effective by both villages. Importantly, water

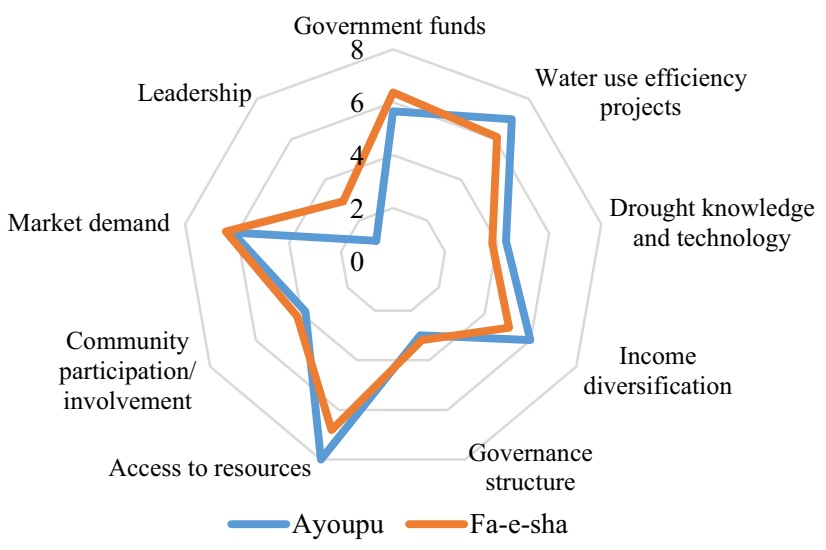

Fig. 4 Administrative village-wise perception on effectiveness of policy to deal with drought (10-highly effective, 1-not effective) in the study villages of Yunnan Province, China. Source Focus group discussions, 2013-2015

supply was perceived as the government's responsibility and considered to be distributed at household level.

\subsection{Case Study 2: Agricultural Diversity in Longyang}

The impacts of the 2009-2010 drought on agriculture and tree crops in Longyang ranged from marginal decreases in yield to complete crop failure in some areas and for some crop types. The key informant interviews and household surveys across the studied villages in Haitang, Shuiyan, and Xinzhai showed that rainfall is increasingly inconsistent and declining, but temperature is increasing. This was also verified by the temperature and precipitation trends based on the information provided by Longyang Meteorological Bureau for the period 1980-2014. Annual temperature increased at a rate of $0.5^{\circ} \mathrm{C} /$ decade $\left(R^{2}=0.6713\right)$, and a warming trend of $0.33{ }^{\circ} \mathrm{C} /$ decade $\left(R^{2}=0.5672\right)$ was observed for summer, and a warming trend of $0.59^{\circ} \mathrm{C} /$ decade $\left(R^{2}=0.5388\right)$ was observed for winter temperatures (Fig. 5). This indicates stronger warming in winter than in summer. The annual temperature change trend in Longyang is higher for summer temperature, and winter

Table 3 Key Informants' response on the project development process in Luling, Yunnan Province, China. Source Authors' field survey, 2013-2015 $(n=16)$

\begin{tabular}{|c|c|c|c|c|c|c|}
\hline & \multicolumn{2}{|c|}{ Consulted before the project starts } & \multicolumn{2}{|c|}{ Consulted during the process } & \multicolumn{2}{|c|}{ Informed only after the decision is made } \\
\hline & Yes & No & Yes & No & Yes & No \\
\hline No of responses & 10 & 6 & 2 & 14 & 1 & 15 \\
\hline Percentage & $62.50 \%$ & $37.50 \%$ & $12.50 \%$ & $87.50 \%$ & $6.25 \%$ & $93.75 \%$ \\
\hline
\end{tabular}


temperatures show a slightly higher increase in the warming trend than the Yunnan provincial average. The annual precipitation pattern during the period 1980-2014 shows a decreasing trend, which follows the decreasing trend of the provincial annual precipitation.

After the severe droughts in 1997 and massive floods in 1998, on-farm tree planting or "Sloping Land Conversion Program (SLCP)," also known as the "Grain for Green Program," was introduced to convert cropland on steep slopes to forest to reduce water-induced disasters. These actions resulted from the realization that droughts and floods were at least partially caused by farming on steep slopes and deforestation (Bennett 2008). SLCP was implemented in 1999 as a pilot in Sichuan, Shaanxi, and Gansu Provinces but expanded nationwide in 2001. The Baoshan City government also initiated the expansion of walnut production under the SLCP, with the goal of planting over 30,000 hectares in the study area. It was found that each village had integrated trees into agricultural production systems in different ways, which diversified the landscape and helped farmers to cope with the 2009-2010 drought.

In Haitang, walnut stands were well established by the time the field survey was conducted and new stands of walnuts has recently been planted with support from the
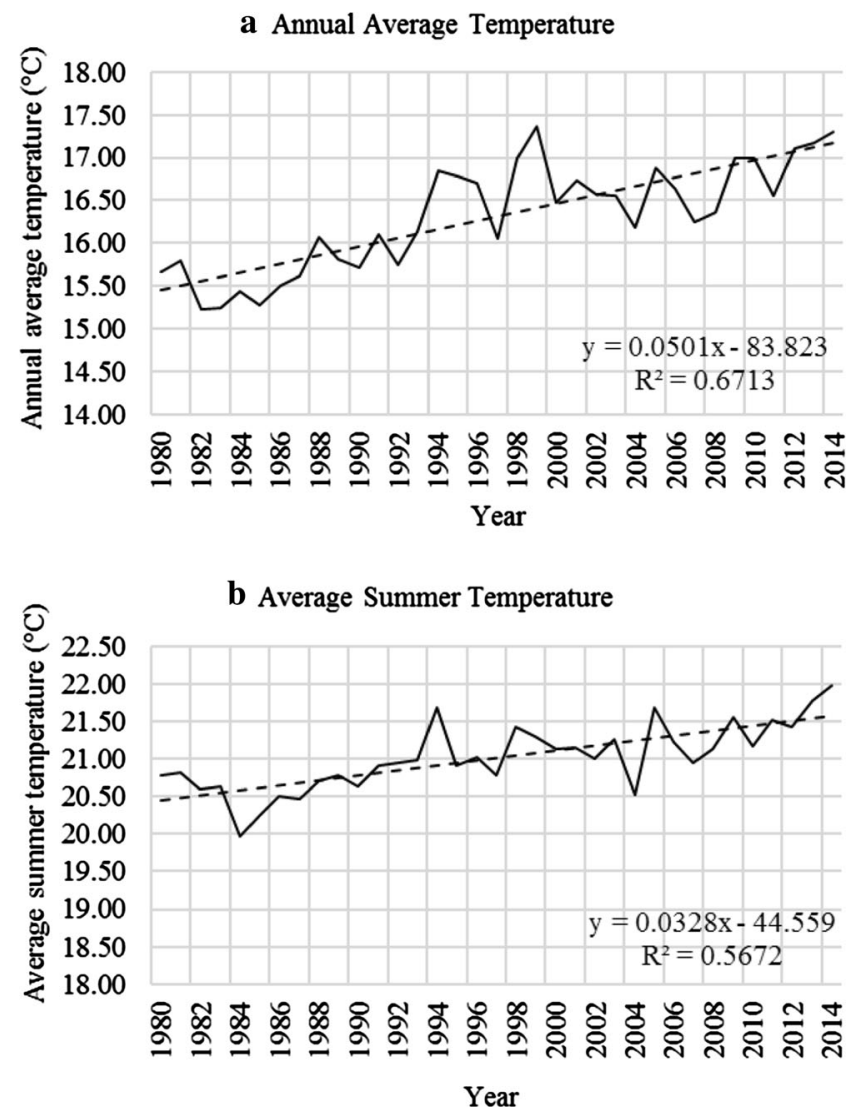

SLCP. Haitang also promoted agricultural production, collected non-timber forest products, and harvested tree products (primarily walnuts, but also Sichuan Pepper, mushrooms). Aromatic tobacco, a cash crop strongly supported by the local government, was the main income source in Shuiyan (65\% of main cash crop income), supplemented by livestock (20\%), forestry $(10 \%)$, and offfarm work $(5 \%)$. As a product of the walnut promotion policy of Baoshan City, stands of young walnuts were also planted in Shuiyan. Xinzhai primarily grew coffee ( $70 \%$ of main cash crop income), supplemented by livestock (15\%), and fruits $(15 \%)$.

The household survey showed that due to the severe drought in 2009-2010, yields from agricultural crops significantly dropped in all the studied villages. It was estimated that all crop types experienced over $30 \%$ yield loss, with spring crops experiencing $70-100 \%$ yield loss (with the exception of wheat in Shuiyan). Due to water scarcity, a number of wet paddy fields (only found in Shuiyan and Xinzhai) had to be converted into dry lands for the summer season. Secondary data available from Baoshan show that walnuts were affected by drought with a yield loss ranging from 33 to $52 \%$, whereas average crop loss was concentrated near $48 \%$ among Longyang farmers. Coffee in
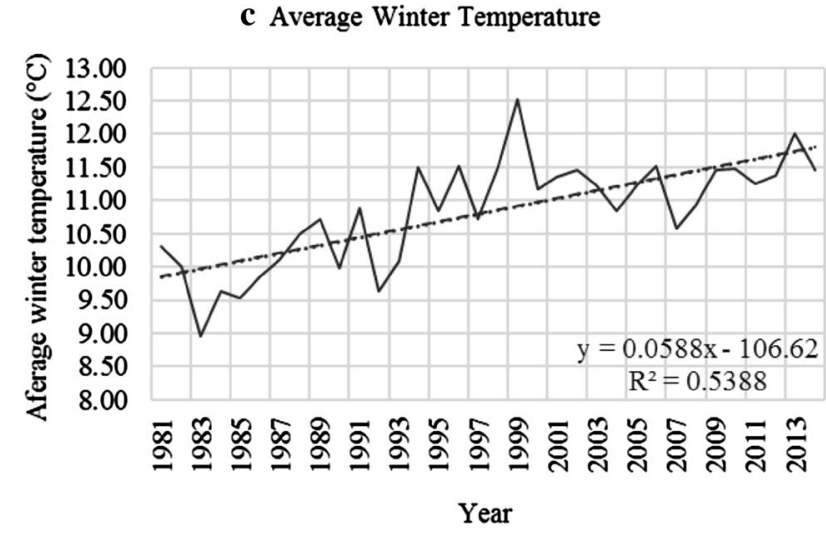

d Annual Precipitation

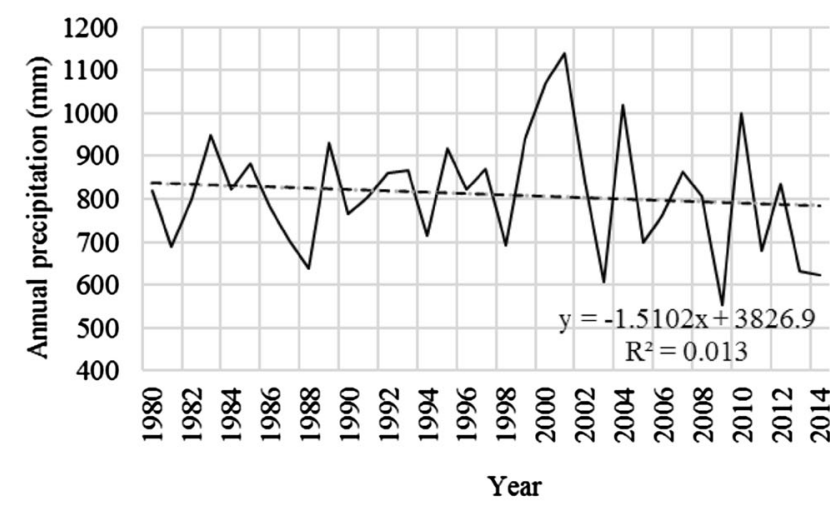

Fig. 5 Average a annual, b summer, and c winter temperatures, and d annual precipitation, for the period 1980-2014 for Longyang County, Yunnan Province, China. Data source Baoshan Meteorological Bureau, Yunnan Province 
Xinzhai, which was not supported by a government agricultural extension program, had $97 \%$ of planted areas affected by drought. The focus group discussions in Haitang and Shuiyan showed that only $10-20 \%$ of the walnut trees planted in 2007-2008 died; about $40-50 \%$ of those planted in 2009 died in the 2009-2010 drought. Analysis of the three main crops in the study area showed that Sichuan pepper suffered almost $72 \%$ yield loss, followed by coffee with $51 \%$ and walnut with $32 \%$ yield losses.

The household survey also found that in Haitang and Shuiyan, farmers dependent on agricultural crops suffered far larger income loss than farmers with forest-related crops (Table 4). Those Xinzhai farmers, in contrast, who were dependent on tree crops bore more loss; but this was largely explained by the inclusion of coffee in estimations of tree crop income (Su et al. 2013).

In addition to crop income losses, households reported increased labor inputs in fetching water for household use, higher medical expenses, and rising prices of rice and livestock feed. Although coffee and walnut tree mortality was significant for some households, most reported their intention to replant these lost trees. However, the contribution of increased income from tree crops did not safeguard households against the overall effects of severe drought because these sites rely heavily on monoculture tree cultivation, and most of these trees heavily rely on water.

\section{Discussions and Lessons}

The findings of the research indicate that farmers' perception about policy effectiveness is guided by government policy and projects implemented at the local level. It was also found that immediate coping options were perceived by farmers as more effective policy measures than longterm adaption strategies. The perception of (climate) risk is highly dependent on the social, cultural, and economic conditions within which people experience the risk, and perception influences their behavior (Patt and Schröter 2008). This research was based on the argument that the selection of policy measures are determined by the nature of the problem/hazard and local geophysical characteristics
(Scheumann and Kraume 2009; Vaidya 2009). A modified framework was used to analyze the effectiveness of farmers' perception and experiences. The discussion was led by a key question: How do the respondents perceive the effectiveness of policy implementation at the local level?

In Luliang, though Fa-e-sha and Ayoupu had similar geographical conditions, because of the easy access to the main road and more projects supported by the government, Ayoupu was perceived less vulnerable than Fa-e-sha. The link to the main road helped farmers to access resources and markets, and contributed to enhancing their adaptive capacity (Burton et al. 2001). Other infrastructure projects like dam construction, water tanks, and irrigation channels were tangible interventions by the government (and companies) and were perceived by farmers to be effective coping strategies (Yang et al. 2016). When the villagers were asked what happens if the water sources dry up, almost all of them said it is not the concern of the farmers because the government should provide water to everyone. The key informants also verified that, in the past, the local government had supplied water by providing water tankers, and even distributed bottled water to every household in case of extreme drought. This indicates a high dependency of farmers on government policy and projects and they are less concerned about their engagement in devising longterm solutions.

In Luliang, men migrated temporarily from villages to cities due to multiple causes: the acquisition of farmland for the construction of reservoirs; the lease of land to companies for tobacco plantations; and the lure of attractive job opportunities outside the village. Young men and women were attracted to migration because they perceived migration as an easy option to earn money rather than working in drought-struck agricultural fields. This finding was supported by the township water manager who indicated that: "Even when the government provides jobs, the young people prefer to go out because they perceived that it is easy money for them." Human mobility for income diversification is also a government priority because of the conviction that the migrant increases their individual contribution to gross domestic product. Success in promoting migration has been one of the criteria used in the evaluation and promotion of local government officials. Although

Table 4 Losses in agricultural versus forestry income in the spring season, 2009-2010, in Longyang County, Yunnan Province, China. Source Su et al. (2013) (Household survey, 2010)

\begin{tabular}{|c|c|c|c|c|}
\hline Village & $\begin{array}{l}\text { Loss of agricultural } \\
\text { crop income } \\
\text { (USD/household) }\end{array}$ & $\%$ & $\begin{array}{l}\text { Loss of tree crop } \\
\text { income } \\
\text { (USD/household) }\end{array}$ & $\%$ \\
\hline Haitang & -380.18 & -49.60 & -505.38 & -39.80 \\
\hline Shuiyan & -483.08 & -40.00 & -65.85 & -11.90 \\
\hline Xinzhai & -419.15 & -21.70 & -3514.24 & -40.40 \\
\hline
\end{tabular}


temporary human mobility helps to bring back remittances, information, and skills, which could initiate new enterprises and livelihood opportunities to deal with droughts (Banerjee et al. 2011), without proper training and skill development, migrants often land in poorly paid jobs that make them more vulnerable not less (Jodha et al. 2002; Glantz and Kelman 2013).

In Longyang, the households who had adopted tree crops coped with drought better than those that did not because the trees are more resilient under climate stress and the income from tree crops provides a safety net (Neufeldt et al. 2009). However, it was found that farmers' choices depend on government policy and programs. The government's extension program in growing tobacco in Shuiyan was successful in reducing the overall yield loss although tobacco was highly affected by drought. In Haitang, the resilience of mature stands of walnut trees and the diversity of income sources helped in securing household incomes during the drought. In Xinzhai, where more than $70 \%$ of household income was from coffee, which was not supported by the government program, the widespread failure of coffee crops made the farmers more vulnerable to drought and forced them to take emergency responses, such as the purchase or rental of water pumps and the migration of women and men for off-farm work. Tree crops are an effective long-term measure to deal with drought, but farmers often opted for the expansion of perennial crops, changing production patterns, adjusting water management approaches in agricultural fields, sale of livestock, engagement in off-farm work, and migration for job opportunities. This is also because tree crops are a longerterm investment. They do not show immediate results, and monoculture plantations increase risk in climate stress.

\section{Conclusion}

Government support helped the farmers to deal with immediate drought, but the same support increased dependency. This increased dependency on government policy and programs during severe drought is also reported in Iran, where vulnerable people's dependency on government support increased after the severe drought (2003-2011) leading to mistrust, especially amongst those who found themselves ineligible or unable to access assistance (Keshavarz et al. 2013). In order to encourage people to respond to drought in a responsible manner, research in Mozambique emphasized that people need to understand how climate change/drought may place them at greater risk, and people should play a larger role in designing response strategies (Patt and Schröter 2008). A low level of awareness about climate change/drought increases dependency on government policy and thus influences community perception about the effectiveness of policy implementation at the local level.

The two case studies also provide empirical evidence that farmers' perception about the effectiveness of policy implementation is guided by government policies and programs. The government policy on water conservancy projects helped the farmers in Luliang to cope with drought immediately, however, made them less responsive to adopt long-term adaptation strategies. In Longyang, farmers had a tendency to value short-term goals (profitability) over long-term benefits (agricultural diversity). The high dependency on government policy made the farmers more vulnerable and less resilient to address future drought. Therefore, farmers' perception about the effectiveness of policy implementation largely depends on short-term, immediate, and tangible results and seldom on long-term solutions. In addition to the government's policy support as an immediate coping measure for drought, it is also important to reduce risks by developing better awareness about climate change/drought and its impacts, understanding drought hazards, and taking appropriate measures for long-term adaptation.

Acknowledgements The study was supported by the University of Chinese Academy of Sciences (UCAS)/Kunming Institute of Botany (KIB), the Himalayan Climate Change Adaptation Programme (HICAP) funded by the governments of Norway and Sweden, and core funds of the International Centre for Integrated Mountain Development (ICIMOD). The authors acknowledge the support of the Summer Institute for Disaster and Risk Research implemented by Beijing Normal University (BNU) and funded by the State Administration of Foreign Experts Affairs, Ministry of Education, and BNU. Special thanks to UCAS/KIB, Dr. David Molden, Dr. Eklabya Sharma, Dr. Aditi Mukherji, Dr. Ning Wu, Dr. Shaoling Yi, Dr. Dhrupad Choudhury, Nand Kishor Agrawal, and Gauri S Dongol for their support and valuable inputs. We would also like to thank Carly Biondi from the World Agroforestry Centre (ICRAF), and IJDRS reviewers and editors for their inputs. Support and cooperation of the local community and stakeholders, and field support from students and translators are greatly appreciated. The views and interpretations in this publication are those of the authors.

Open Access This article is distributed under the terms of the Creative Commons Attribution 4.0 International License (http://crea tivecommons.org/licenses/by/4.0/), which permits unrestricted use, distribution, and reproduction in any medium, provided you give appropriate credit to the original author(s) and the source, provide a link to the Creative Commons license, and indicate if changes were made.

\section{References}

Adger, W.N., N.W. Arnell, and E.L. Tompkins. 2005. Adapting to climate change: Perspectives across scales. Global Environmental Change 15(2): 75-76. http://linkinghub.elsevier.com/retrieve/ pii/S0959378005000166. Accessed 9 Jan 2015.

Baker, D., and J.N. McLelland. 2003. Evaluating the effectiveness of British Columbia's environmental assessment process for First 
Nations' participation in mining development. Environmental Impact Assessment Review 23: 581-603.

Banerjee, S., J.Y. Gerlitz, and B. Hoermann. 2011. Labour migration as a response strategy to water hazards in the Hindu KushHimalayas. Kathmandu, Nepal: International Centre for Integrated Mountain Development (ICIMOD) http://lib.icimod.org/ record/26921. Accessed 9 Jan 2015.

Bennett, M.T. 2008. China's sloping land conversion program: Institutional innovation or business as usual? Ecological Economics 65(4): 699-711.

Burton, I., B. Challenger, S. Huq, R.J.T. Klein, and G. Yohe. 2001. Adaptation to climate change in the context of sustainable development and equity. In Climate change 2001: Impacts, adaptation, and vulnerability, ed. J.J. McCarthy, O.F. Canziani, N.A. Leary, D.J. Dokken, and K.S. White, 876-912. Cambridge: Cambridge University Press. http://www.ipcc.ch/ipccreports/tar/ wg2/index.php?idp=641. Accessed 9 Jan 2015.

Castellan, C.M. 2010. Quantitative and qualitative research: A view for clarity. International Journal of Education 2(2): 1-14.

Chen, H., J. Wang, and J. Huang. 2014. Policy support, social capital, and farmers' adaptation to drought in China. Global Environmental Change 24: 193-202. http://www.sciencedirect.com/ science/article/pii/S0959378013002173. Accessed 20 Feb 2015.

Eakin, H., and M.C. Lemos. 2006. Adaptation and the state: Latin America and the challenge of capacity-building under globalization. Global Environmental Change 16(1): 7-18. http:// linkinghub.elsevier.com/retrieve/pii/S0959378005000713. Accessed 9 Jan 2015

European Environment Agency. n.d. Policy effectiveness evaluation. European Environment Agency, Denmark. http://www.pedz.unimannheim.de/daten/edz-bn/eua/04/Effectiveness_FINAL_lowres.pdf. Accessed 28 Jan 2016.

European Environmental Agency. 2009. Diverting waste from landfill. http://www.eea.europa.eu/publications/diverting-wastefrom-landfill-effectiveness-of-waste-management-policies-inthe-european-union. Accessed 28 Jun 2016.

Gillham, B. 2005. Research interviewing: The range of techniques. A practical guide book. New York: Open University Press.

Glantz, M.H., and I. Kelman. 2013. Thoughts on dealing with climate change...as if the future matters. International Journal of Disaster Risk Science 4(1): 1-8. http://link.springer.com/10. 1007/s13753-013-0002-1. Accessed 13 Aug 2015.

Jodha, N., B. Bhadra, N. Khanal, and J. Richter. 2002. Poverty: Issues and options in mountain areas, with specific focus on China. In Poverty alleviation in mountain areas of China, Proceedings of the international conference held from 11-15 November 2002, Chengdu, China, ed. B. Bhadra, J. Richter, N. Khanal, and N.S. Jodha, 1-32. Germany: InWEnt gGmbH.

Keshavarz, M., E. Karami, and F. Vanclay. 2013. The social experience of drought in rural Iran. Land Use Policy 30(1): $120-129$.

Li, H., J. Gupta, and M.P. Van Dijk. 2012. China's governance structure on drought disaster in rural areas. Disaster Advances 5(4): 733-737.

Li, H., J. Gupta, and M.P. Van Dijk. 2013. China's drought strategies in rural areas along the Lancang River. Water Policy 15(1): $1-18$.

Matland, R.E. 1995. Synthesizing the implementation literature: The ambiguity-conflict model of policy implementation. Journal of Public Administration Research and Theory: J-PART 5(2): 145-174. http://www.jstor.org/stable/1181674?seq=13. Accessed 17 Feb 2016.

Mimura, N., R.S. Pulwarty, D.M. Duc, I. Elshinnawy, M.H. Redsteer, H.Q. Huang, J.N. Nkem, and R.A. Sanchez Rodriguez. 2014. Climate change 2014: Impacts, adaptation, and vulnerability. Part A: Global and sectoral aspects. Contribution of Working
Group II to the fifth assessment report of the Intergovernmental Panel on Climate Change, ed. C.B. Field, V.R. Barros, D.J. Dokken, K.J. Mach, M.D. Mastrandrea, T.E. Bilir, M. Chatterjee, K.L. Ebi, Y.O. Estrada, R.C. Genova, B. Girma, E.S. Kissel, A.N. Levy, S. MacCracken, P.R. Mastrandrea, and L.L. White, 869-898. Cambridge: Cambridge University Press.

Mingchai, C., and P. Yossuck. 2008. Organic farming: Effectiveness of policy implementation in the north of Thailand. In GMSARN [Greater Mekong Subregion Academia and Research Network] International Conference on Sustainable Development: Issues and Prospects for the GMS. http://dl.gmseenet.org/handle/ 123456789/887. Accessed 28 Jun 2016.

Neufeldt, H., A. Wilkes, R.J. Zomer, J. Xu, E. Nang'ole, C. Munster, and F. Place. 2009. Trees on farms: Tackling the triple challenge of mitigation, adaptation and food security. World Agro. World Agroforestry Centre, Nairobi, Kenya. http://www.worldagrofor estrycentre.org/downloads/publications/PDFs/mitigation-adapta tion-food-security.pdf. Accessed 24 Nov 2016.

O'Toole, L.J.J. 2000. Research on policy implementation: Assessment and prospects. Journal of Public Administration Research and Theory: J-PART 10(2): 263-288.

Patt, A.G., and D. Schröter. 2008. Perceptions of climate risk in Mozambique: Implications for the success of adaptation strategies. Global Environmental Change 18(3): 458-467.

Potter, C.C., and J. Harries. 2006. The determinants of policy effectiveness. Bulletin of the World Health Organization 84(11): 843.

Pradhan, N.S., V.R. Khadgi, and N. Kaur. 2014. The role of policies and institutions in adaptation planning: Experiences from the Hindu-Kush Himalaya. In Community-based adaptation to climate change: Emerging lessons, ed. J. Ensor, S. Huq, and R. Berger, 95-110. Burton, Rugby, UK: Practical Action Publishing.

Pradhan, N.S., V.R. Khadgi, L. Schipper, N. Kaur, and T. Geoghegan. 2012. Role of policy and institutions in local adaptation to climate change. Kathmandu, Nepal: International Centre for Integrated Mountain Development (ICIMOD).

Sadler, B. 1996. International study of the effectiveness of environmental assessment - Final report. Environmental assessment in a changing world: Evaluating practive to improve performance. Ottawa: Canadian Environmental Assessment Agency.

Scheumann, R., and M. Kraume. 2009. Influence of different HRT for the operation of a submerged membrane sequencing batch reactor (SM-SBR) for the treatment of greywater. Desalination 248: $123-130$.

Schutt, R.K. 1996. Qualitative data analysis. In Investigating the social world, 320-357. Sage. http://www.sagepub.com/upmdata/43454_10.pdf. Accessed 8 Apr 2015.

Sivakumar, M.V.K. 2013. Weather and climate extremes: Need for and importance of the journal. Weather and Climate Extremes 1: $1-3$.

Smit, B., and J. Wandel. 2006. Adaptation, adaptive capacity and vulnerability. Global Environmental Change 16(3): 282-292. http://linkinghub.elsevier.com/retrieve/pii/S0959378006000410. Accessed 9 Jan 2015.

Su, Y., J. Lu, S. Manandhar, A. Ahmad, and J. Xu. 2013. Policy and institutions in adaptation to climate change: Case study on tree crop diversity in China, Nepal and Pakistan. Kathmandu, Nepal: International Centre for Integrated Mountain Development (ICIMOD).

Su, Y., J. Xu, A. Wilkes, J. Lu, Q. Li, Y. Fu, X. Ma, and R. Edward Grumbine. 2012. Coping with climate-induced water stresses through time and space in the mountains of southwest China. Regional Environmental Change 12(4): 855-866. http://link. springer.com/10.1007/s10113-012-0304-7. Accessed 7 Mar 2015. 
Teng, F., and A. Gu. 2007. Climate change: National and local policy opportunities in China. http://www.feem.it/Feem/Pub/Publica tions/WPapers/default.htm. Accessed 9/1/2015.

Vaidya, R.A. 2009. The role of water storage in adaptation to climate change in the HKH region. In Sustainable mountain development, ed. H. Ouyang, M. Eriksson, and R.A. Vaidya, 10-13. Kathmandu, Nepal: International Centre for Integrated Mountain Development (ICIMOD).

Wang, J., and Y. Meng. 2013. An analysis of the drought in Yunnan, China, from a perspective of society drought severity. Natural Hazards 67(2): 431-458. http://link.springer.com/10.1007/ s11069-013-0572-7. Accessed 31 Aug 2015.
Xinhua. 2010. Chinese premier urges redoubled drought-relief efforts. http://english.sina.com/china/2010/0321/309861.html. Accessed 9 Jan 2015.

Yang, H., G.B. Villamor, Y. Su, and M. Wang. 2016. Land-use response to drought scenarios and water policy intervention in Lijiang, SW China. Land Use Policy 57: 377-387.

Yang, K., and M. Holzer. 2006. The performance-Trust link: Implications for performance measurement. Public Administration Reviews 66(1): 114-126.

Zou, M., and Y. Yuan. 2010. China's comprehensive disaster reduction. International Journal of Disaster Risk Science 1(1): 24-32. 